\title{
BEYOND RHETORICS: UNLOCKING THE POTENTIALS OF AFRICAN INDUSTRIALISATION
}

\author{
Nkemdili Au. Nnonyelu \\ Nnamdi Azikiwe University, Awka.
}

\begin{abstract}
:
Industrialisation is largely acknowledged as one of the drivers of development, economic progress and social welfare. In most African countries however, the drive towards industrialisation has largely been inchoate, and driven by rhetoric without commensurate proactive actions. Given the evidence of woeful state of industrialisation in Africa, the often trumpeted industrial policies do not seem propitious for the promotion of industrial activities. The paper rejects the official platitudes that have been mouthed by policy makers as based on a faulty premise. The paper appreciates the stumbling blocks and dilemmas that African countries face as global latecomers to contemporary industrialisation, but calls for a paradigm shift in policy, a comprehensive redesigning of industrial policies, emplacement of pragmatic enablers and systematic implementation of these policies, that will provide new options and route to industrialisation.
\end{abstract}

Keywords: Industrialisation, Industrial Policy, Rhetorics, Enablers, Unlock.

\section{Introduction:}

More than half a century that majority of modern African States gained political independence from their former colonial masters, most of these countries are still enmeshed in their traditional role of production of raw materials. Far from being industrialised (see Grabowski, 2015) Africa is seen as the least industrialised continent of the world, (ECA, 2013), with staggering statistics that put a lie to all the claims made by different countries about their commitment to industrialise.

On the average, more than 70 percent of the African population live in poverty on less than 2 dollars a day, and majority of the populace are without jobs, most thrown into the informal sector, a condition described as disguised unemployment (Stigliz, 2016). Africa, a continent disparagingly referred to as the dark continent by critics, unwittingly justifies this allusion by a humongous lack of access to electricity by more than two third of its population. Insecurity is rife, as access to health care for the citizens is pitiable, with life span for Sub Saharan Africa standing at 47 years. Human development indicators have remained dismal, and this is despite the impressive growth rates posted by many African countries including Ghana, Botswana, Rwanda, Ethiopia and Nigeria etc (Oyebanke (2015), ECA \& AU (2013) and OECD (2013)).

The growth observed in the economy of African countries has not been able to inspire structural transformation into higher productivity sectors on the continent, a classic case of growth not being coterminous with development. African countries account for a negligible share of global manufacturing output or the manufacturing value added which still accounts for 1.6 percent of the global total. Moreso, Africa's manufacturing value added depicted in Gross Domestic Product (GDP) per capita has infact declined from 12 percent in the 1970s to about 9 percent in the 2010s (see Stigliz, 2016). Africa can be described truthfully as a case of seeming structural change without industrialisation and diversification (Carmighani and Mandevile, 2010), which is anomalous.

The nightmare that has been Africa's lot in the quest for industrialisation may be directly linked to the nature, content, and purpose of policies that have been used as guiding principles or 
barometers for industrialisation, and general lackadaisical attitude to implementation of these policies. Policy refers to a set of instruments and interventions geared towards industrial development (Gumede, 2015, Altenburg, 2011). To Chimoli, Dosi and Stigliz (2009), "industrial policy is broadly seen as the checklist of ideas, innovation, education, trade, sectoral and competitive policies employed by Governments to induce structural change and industrialisation. Industrial policy, therefore refers to the articulation of the totality of the manufacturing process, what is to be manufactured, for whom and by whom and also the body of laws (regulations), in most cases codified, that will guide the entire process. Industrial policy is crucial in delineating the character of industrialisation and its outcome. The importance of industrial policy is seen in the success of industrialised economies. A good industrial policy is the dividing line between countries that have successfully industrialised, and those still trapped in the non-industrial sector. Industrial policy has expanded its goal, and is not merely diversification and increasing the value added in manufacturing but now embraces the increase in productivity within identifiable sectors, and also enhance the free movement of workers from areas of low productive activities like in agriculture and informal services, to high productive activities in modern services and industry (see Hausman, Rodrick and Sabel, 2008). The closure of once thriving industries, the production at less than optimal capacity, the increasing demand for industrial products that are out of stock, or never in existence, the flooding of African market with substandard products, goods and services, produced outside the continent make it compelling that industrial policies that inform the nature of industrialisation be reexamined, and if necessary, have a changed approach to development of the continent. Given the fact that the history of developed societies is the story of industrialization, it is imperative that an appraisal be made of the specific industrial policies that have driven the quest for industrialisation in Africa and why currently, Africa has not been able to exploit its rich resources and unleash its potentials.

What are the constraining factors that have impeded the desire for Africa to industrialise? Is the problem due to inappropriate policies? A school of thought believe that the problem does not lie merely in the industrial policies per se, but in their implementation (see Trade and Industrial Policy Strategies, 2016). The other school of thought that still resonates, looks at the industrial policies that have been promulgated over the years as faulty and unsustainable. More importantly these industrial policies cannot take Africa out of the non-industrialisation trap (Ake, 2001) and calls for an overhaul of these policies to reflect the socio-political cum economic environment of Africa. Industrialisation refers to the production process that employs the use of machines, more than human labour, and emphasises manufacturing as the key or engine of development. It refers broadly to the transformations that societies experience in their transition from an agricultural to an industrial economy. Industrialisation therefore encompasses the process of raising the manufacturing output, or expanding the manufacturing sector (Cimoli et al, 2009). This transition is depicted by the different stages societies go through, and these include:

Stage One: Production of primary goods;

Stage Two: Pervasiveness of industrial activities, and the increasing role of manufacturing sector;

Stage Three: The emergence of developed economy (Malam, Steenkamp, Rossouw, and Viviers, 2014). From the above, it is obvious that Africa is still in its infancy - Stage One. There is nothing however to suggest that societies must go through this unilineal evolutionary process, and that they cannot industrialise without necessarily passing through the aforestated stages. It however needs to be stated that there is a consensus of opinion in the literature that 
industrialisation is essential for sustainable development, a major plank of United Nations Agenda on Sustainable Development Goals. Furthermore, there is an almost unanimous affirmation among scholars in the literature on the importance of industrialisation as the foundation on which all advanced economies have been built on (see De Vries G., Timmer and De Vries K., 2013; Trade \& Industrial Policy Strategies (TIPS), 2016; Soludo, Ogbu and Chang, (Eds), (2004). As earlier stated, we reiterate our initial observation that a cursory look at the industrialisation drive in Africa, will highlight the preponderance of industrial policies, but these have not been translated into industrialisation of the continent. Why is this so? To unravel the puzzle, there is a dire need for the interrogation of the different industrial policy options that have been successively applied in Africa. A review of some of these policies cum strategies may suffice.

\section{A Review of Industrial Policies in Africa:}

Since independence, Africa has grappled with different industrial policies. At the level of the continental body African Union (AU), or Organisation of African Unity (OAU) as it was then known, African Heads of States and Governments came together in 1980 to promulgate what was commonly known as Lagos Plan of Action. It explicitly stated the pivotal need to see to the realisation of a plan for the industrialisation of Africa, asking African States to give industrialisation a pride of place in their development plans. The Lagos Plan of Action also called for a simultaneous regional cooperation towards the embedding of industrial activities at the regional levels. It anticipated the creation of regional hubs that will midwife and crystallize industrial complexes. Following this in 1991, the leaders of Africa convened again to proclaim the Abuja Treaty which set the target of a harmonized industrial policy that will prepare the ground for Joint Industrial Development at the regional level. This is supported by several working documents released by the Regional Economic Communities in Africa, ECOWAS, SADC COMESA, EAC, to mention but a few (see Bruce, Karaki and Woolfrey, 2018).

In 2008, African Union adopted the African Industrial Development Action (AIDA) Plan, very much like the preceding policies to emphasize the need for an industrialisation policy that will leverage on the economies of scale. The purpose of the policy is two pronged: (a) to highlight a detailed examination of the extant state of industry on the continent delineating the type of industrial policies being pursued, (b) it also specifies other policy recommendations and options for countries in Africa (UNECA, 2011). Following this, the Conference of African Ministers of Industry (CAMI) developed the proposals for an Industrial Development Decade for Africa (IDDA), New Partnership for Africa's Development (NEPAD), the African Productivity Capacity Initiative (APCI) and the Plan of Action for Accelerated Industry Development (UNECA, 2011).

At the Pan Continental level, needless to say, these initiatives did not transform the lack of activities in the industrial sector, as the continent continued to advertise the failures that pockmark industrial development leading to the contention that best industrial policy options however need to be relatively country specific. Attempts were made to develop policies that will capture the regional diversities and peculiarities. In all the summits organised by the regional bodies, one common thread is the emplacement of the industrialisation agenda on the front burner of regional discourse. The upsurge in the rhetoric of policy makers in Africa has led to the promulgation at the regional level, a reincarnation of what is in existence at the national levels, of medium and long term industrial development policies. These include: the East African Community (EAC) Industrialisation policy 2012 - 2032, approved in 2011. There 
is also the approval in 2015 of a 48-year industrial development plan (2015 - 2063) by the South African Development Community (SADC). This is to drive the industrialisation policy for some time to come. In West Africa, there is in existence West African Common Industrial Policy (WACIP) even though like other regional initiatives has had minor impact on national policies, as some countries including Nigeria mount obstacles to protect presumably their own autonomous factories, like denial of import licenses, promulgation of import prohibition list which to all intents and purposes is against the spirit and letter of the policy.

The existence of these regional policies has not precluded the emergence of national industrial development policies. We recollect amongst these the Vision 2020 document in Nigeria. In 2014, Economic Report on Africa suggested the strong need for African countries to introduce credible industrial policies to assist in the promotion of genuine industrial transformation in these countries. The adoption of dedicated industrial policy frameworks even before then, had proceeded apace - Ghana (2011), Rwanda (2011), crisis hit Zimbabwe (2012), Botswana (2014), Kenya (2015) (see Whitfield, Therkildsen, Buuv and Kjaer, 2015).

An intersection between politics and policy and the internal dynamics of the political economy in most African States act in contradiction to the rhetorics of industrial development by policy makers (Vanheukelom and Bettelsman-Scott, 2016). Without doubt, the regional integration benefits have not yielded the desired benefits - no thanks to the character of the post-colonial state in Africa, and its corrupt, prebendal and patrimonial leadership, and as highlighted by Hausmann et al (2008) the different forms of market failure - public input failure, coordination failure, and self-discovery failure. The political economy theory explains clearly the relationship between the nature of political leadership in Africa and the type of industrial policies that have arisen.

It is also pertinent to restate the industrial policies cum strategies that sought to provide the missing link affecting industrialisation in Africa, and with these expose the inadequacy of these policies and the validity of the political economy theory as explanatory model. These include:

(a) Import Substitution Industrialisation (ISI): The major plank of the policy of ISI is to manufacture local products as substitutes for the imported goods. It is driven by the need to conserve foreign exchange and limit dependence on foreign products by increasing the tempo of domestic production. It was very popular among newly independent African countries in the 1960s and 1970s. Suffering from export pessimism, ISI focus was to strengthen the domestic production of goods that were previously imported (see Eldine - Bessam, Gadow and Arnold, 2012). Import Substitution Industrialisation developed on the premise of decolonisation and the euphoria of independence and new state experience. It was also influenced by state rule, the touted success of central planning in Soviet Union, posted during the $2^{\text {nd }}$ World War (Riedel nd) and thereafter, the ideology was that the state needed to intervene to deal with issues relating to balance of payment problems, protect newly developing industries through tariffs etc, but this proved unsatisfactory, unsustainable and unworkable. The negative side effects manifested in slow growth, hyperinflation, and debt crisis leading to forced abandonment of ISI (Cardoso, 2009).

Globally, not only in Africa but elsewhere, Import Substitution Industrialisation "was both unsustainable over time and produced high economic and social costs" (Franko, 2007:66). It failed in its primary assignment of producing local substitutes, accumulation of capital to aid diversification, and thus was promptly critiqued by neo-liberal ideologues who feasted on free 
trade menu eulogising privatisation of state owned enterprises, deregulation, trade liberalism, and export promotion. The theoretical premise of neo-liberalism which informed largely this new persuasion gained orthodoxy under the umbrella of Washington Consensus which has received a large dose of interest in the literature. Washington Consensus refers to the set of blue prints, or economic policies articulated by International Financial Institutions (Bretton Woods) notably the World Bank, International Monetary Fund and United States Treasury Bank, that are intended to bring universal relief or prescriptions to countries in need of industrialisation and development through reforms and institution building (Williamson, 2004:2). It was therefore the recipes as dished by the advocates of Washington Consensus that propelled the ascendancy of the tenets of Structural Adjustment Programme (SAP) including deregulation, and constriction of, or withdrawal of the State from Businesses, and the unrestrained dominance of market forces. The more than two decades adherence to the dictates of Washington Consensus did not yield salutary outcomes leading to some critics labelling it Washington Confusion (Stiglitz, 1998) while others said that it is better seen as an oxymoron.

The central ideas of Washington Consensus, which Williamson (2004) fondly refers to as Ten Commandments include (a) Fiscal discipline, (b) Reorientation of public expenditures, (c) Tax reform, (d) Financial liberalisation, (e) Unified and competitive exchange rates, (f) Trade liberalisation, (g) Openness to foreign direct investment, (h) Privatisation, (i) Deregulation and (j) Property rights (see Rodrick, 2002). Many of these have been colossal failures, for instance both deregulation and privatisation have been used deceitfully by the ruling elite in African countries to seize national wealth and common patrimony by handing it over to friends, cronies and surrogates. In Nigeria, the concessioning of public companies like National Electric Power Authority (NEPA) to private individuals, under the guise of privatisation has meant cascading darkness rather than light. In most countries in Africa, privatisation of State Owned Enterprises is a euphemism for corruption, arousing national sensibilities and resentment. For trade liberalisation, it may be inconceivable to think of free trade in the real sense, when developing countries lack the necessary financial muscle, institutional platform to compete on the same terms with entrenched capitalists. Free trade is unrealistic when the advanced capitalist economies continue their restriction of trade through Tariffs, new trade barriers etc. Also given that international trade is dominated by cartels of Multi and Trans National Corporations (MTNCs) free trade particularly for Newly Industrialising Countries (NICs) is largely illusory. Literature is replete with instances of repatriation of humongous sums of money by Multi National Corporations to their home economies, rather than re-investing these in their places of operation.

(b) Export Oriented Industrialisation Strategy (EOIS): This policy has not fared well either for obvious reasons (Shakya, 2010). Against the backdrop of the prevailing ideas of comparative advantage in the $70 \mathrm{~s}$ and $80 \mathrm{~s}$, as advised by the International Donor Agencies, several African countries embraced the policy of producing goods for the global market. However, this policy was skewed towards the production and export of raw materials, mainly in the extractive industries to service the business operations of the metropolitan economies. Export promotion, according to Shafaedin (2006) is defined as a strategy for which the incentive structure is neutral between production for the domestic market and for export, and between the purchase of domestic goods and foreign products. The advocates of neo-liberalism have consistently espoused the benefits of free trade, without going deep to see through the effects of this policy on the development of infant industries. The philosophy of export promotion has not really proved beneficial and realistic as Africa continues to be a dumping ground of all types of foreign products, including toxic wastes, tooth picks, nails etc. The 
suppression of African domestic markets by imported goods goes to show that the policy of export promotion has not worked. What have largely been exported over the years come from the extractive industries, minerals, and other primary products. Locally manufactured products are rarely seen in African markets, how they can then dominate foreign markets is difficult to comprehend. The saying that you can only give what you have is instructive in this regard. Share of locally manufactured products in Africa is still very negligible. This policy aimed at encouraging the process of Africa's industrialisation and set the region on an export diversification route (Stiglitz, 2016) has therefore not worked.

(c) Trade Liberalisation: This is driven by the principle of free enterprise, where economic activities (products and services) crisscross from one end of the globe to the other with minimal restrictions. It is anchored on removal of all restrictions and has a prism of the world as one integrated whole. In reality however, countries continue to take steps to protect their economies, as even seen currently in the trade war not only between United States of America (USA) and Peoples Republic of China, but even among supposed friends and allies like the United States and several European Countries also represented by the European Union (EU). Even the United States and Canada, in the past few weeks have been engaged in hostile verbal and economic exchanges. It reveals something more sinister than what is seen, the primacy of national economic interest. Moreso, the claim about free trade is superfluous, as the global market is increasingly dominated, if not held hostage by the massive power of Trans National Corporations. The role of MNCs/TNCs in industrialisation has largely been contentious. While it is conceded that these large corporations have introduced some form of assistance (capital, technology etc) into their operational areas of business, the fact that a disproportionate share of profits is returned to the metropolitan (home) base of the corporations without reinvesting, is a significant cause of anxiety and de-industrialisation. This explains why in the eyes of many, Foreign Direct Investment (FDI), Foreign Aid, Foreign Capital are seen as more mythical than reality.

\section{Identifying Challenges and Problems:}

The quest to industrialise in Africa has not primarily removed the fundamental obstacles that inhibit the process. One of the most significant is the

a) Sordid State of Infrastructure in Africa: Underdeveloped infrastructure in Africa has been a long standing barrier to industrialisation and economic transformation (Cooke and Brownie, 2014). It is trite that electricity (power) is a fundamental requirement for industrialisation, but in Africa an estimated 70 percent live without access to electricity, a far cry from situations in other climes and regions like Latin America, East Asia, Pacific, where only about 10 percent do not have access (Cooke and Brownie, 2014). Given this scenario, it is difficult to imagine how Small, Micro and Medium Enterprises (SMEs) will survive. This is exactly why the carcases of abandoned, unsuccessful enterprises litter the environment. The decrepit state of roads, inadequate and in most cases, non-existent railways, ill-equipped and dysfunctional ports are some of the basic challenges facing Africa as it seeks to industrialise. Today, hitherto motorable roads have become impassable. Africa has fewer kilometres of roads than it did 30 years ago, and has the highest cost of transporting goods globally. The paved road density in Africa is $31 \mathrm{~km}$ per 1000 square metres of land, compared with $134 \mathrm{~km}$ in the rest of the developing world (UNCTAD, 2013). Indeed, to address the huge infrastructural gap, it has been estimated that a total sum of 75 billion dollars per annum (UNCTAD, 2013) is required to tackle the challenge, at least for a period of ten years. 
b) Wrong Policies and Policy Inconsistency: Industrialisation has suffered reverses in Africa largely due to faulty industrial policies, policy somersaults, where policies are not systemically implemented, but abandoned midstream. Tracking devices are poorly developed and inadequate. The necessary inquiry or careful investigation of the perceived problem is not done before embarking on new policies. As dictated by foreign monopoly capital, most African societies have embraced privatisation of public enterprises, as panacea to the problem besetting development, particularly those at the commanding heights of the economy and the experiences have been devastating. These privatised firms have not been able to stay afloat, some unashamedly asking for all sorts of assistance including moratorium on payments of outstanding taxes and returns. In Nigeria, many years after the takeover of National Electric Power Authority (NEPA) or Power Holding Company of Nigeria (PHCN) and its concessioning to private hands, Nigeria has not been able to generate more than 4,000 Mega Watts of electricity. Nigerian president, Muhammadu Buhari, publicly wondered recently, in an effusive show of frustration "Where is the power, after spending more than 16 billion dollars in a previous administration?". Ditto for most other public enterprises that have been privatised. It is not that privatisation per se is bad, but the way it is done in Nigeria is used for settlement of campaign or election finances, cronies and kinsmen who may not have the right mind set, even the requisite entrepreneurial skill to transform the ailing companies.

c) Globalisation as Challenge to Industrialisation: The common refrain that the world is a global village does not truly capture the danger inherent in this widespread phenomenon of globalisation. Its pervasive impact, was duly observed by Okebunor \& Anugwom (2005:7) who noted that no other phenomenon is seen as more crucial to contemporary development in Africa than globalisation. Globalisation is not only about the shortening of distances between different societies, but the intensity of exchange and interaction between different peoples of the world during which process, values, services, goods and products are shared in a way that reconstructs the world like an integrated whole. Beyond the facade of this integration, is the destruction of a people's culture and productive potentials, whose ways of life are altered fundamentally including values, ethos and mores. It is therefore necessary to call to question the character and thrust of globalisation. Is it one way, unilineal, or both ways? Whose productive capacity is being mortgaged, if not destroyed. The world through globalisation may be misconstrued as being interwoven, but beyond this false integration, is the dominance of a set of values of a given people who are economically and politically advanced over others who are not that developed. This is the scenario of the industrialised world over the less industrialised. As Asobie has correctly observed, globalisation is a euphemism for universalisation of capitalism. Capitalism flourishes on availability of markets for its products, and therefore expecting Western capital to lead the way for the industrialisation of Africa is both contradictory and meaningless. Globalisation has not helped industrialisation of Africa; it has however helped in compounding Africa's woes.

d) Corruption: Corruption is generally seen as the misuse or abuse of public office for private gain (World Bank). Corruption refers to the perversion of society's moral norms, or standards. Many have identified corruption as the greatest threat facing Africa, even the current Nigerian President, Muhammadu Buhari has said severally that it is either Nigeria kills corruption or corruption will kill Nigeria. There are too many vested interests and motives that characterise interpersonal relations, or even the official activities. Therefore, corruption has since been institutionalised in several African societies. Corruption has become a way of life, the norm rather than the exception. It is endemic and embedded in society (Helman and Ndumbaro, 2002:2). In corruption ridden societies, corrupt practises are replicated and reproduced by the 
extant power relation, where occupants of state power and bureaucrats use state resources to advance the interests of family, friends and kindred group. Instances of treasury looting are mind boggling all over Africa. The illicit funds are not used for the industrialisation of the continent, but mainly stashed away overseas in Europe and America, further leaving the continent desolate and plundered. In several African countries, the talk about sharing the national cake or allocation and consumption, not production has become a continental creed. The ownership of corrupt activities, its justification along primordial lines like ethnicity and religion have moved to disable people from making honest efforts.

Therefore, post-colonial African states have become centres of corruption, and ruled by politics of the belly, which provides the incentive for the leaders to eat from the resources of the state (see Bayart, Ellis and Hibou, 1999). Those who have access to the state, or those in the corridors of power, use their influence and connections to line their pockets with illicit funds. The greatest disincentive to industrialisation in Africa, is in my view, the ease with which people who do not have any established business turn into men of money and power overnight. The classification, Businessman, has become a catchword for those who do not have any business, and as Ake (2001) described it, you need not be entrepreneurial or industrious if you have affinity to the seat of power, as access alone confers immeasurable material priviledges. Corruption has engendered a perverted sense of values. In Nigeria alone more than 400 billion dollars is said to have been stolen since the discovery of oil (International Crisis Group, 2006). Reinvesting this humongous sum back into the economy would have quickened the pace of industrialisation. Corruption is still flourishing in several states in Africa, in spite of claims to the contrary. Recovered looted funds are relooted leading to a cycle of looting, or a looting spree. Corruption also has spiral effects on the cost of doing business in Africa. Corruption has effectively banished merit and hard work. Asobie (2014:5) notes that the chief criterion for high reward in contemporary Nigeria is no longer productivity or hard work or even enterprise. It is loyalty, or subservience or monopolistic control of a service line both in public and private sectors. Compassion and humanness - those unique qualities or virtues that define our humanity and even distinguish our race have been replaced by heartlessness, brutality and cruelty, led by triumph of greed and gain, that is, by crass materialism.

e) Cost of Doing Business in Africa: Given the high cost of doing business in Africa characterised by all forms of taxes and tariffs, the near absence of essential utilities that will enhance economic activities like power, roads, etc, industrialisation drive is at its lowest ebb. Another is the spectre of insecurity and the declining capacity of the state to rein in criminals, who have been on something, akin to a terrorising mission. Areas that are prone to banditry, criminality and terrorism will experience not only capital flight, but labour flight as the youthful population that would have been involved in productive activities will relocate to more peaceful and inhabitable places. The situation in North East Nigeria, Sudan, Somalia, and even now, in the Cameroons, is instructive. It is inconceivable to see businesses thriving in such situations.

f) Knowledge Gap: Part of the problems facing majority of African countries on their quest to industrialise is the level of skills and competencies accessible and available to the populace. The content of education is seen by many as poor. Majority of African states have still not provided relevant critical skills that are pivotal in fast tracking the industrialisation of African countries. Several of the graduates of technical colleges do not have the appropriate skills that will properly situate them in industries. Employers of labour are beginning to question the qualities of certificates possessed by young graduates. Curriculum has been found to be irrelevant, and the knowledge is seen as an obstacle towards industrialisation in Africa. The 
new emphasis on Science, Technology, Engineering and Maths (STEM) may help to address the lacuna in knowledge, or the false start in manpower development.

\section{Overcoming the Impediments and Recommendations:}

Industrial policy thrust should address how to confront the obstacles to industrialisation, by incorporating the enablers:

(1) Conducive Socio-Economic Environment: A basic feature that is pivotal in the quest for industrialisation is the guarantee of a conducive economic environment. An environment that is attractive to businesses and manufacturing, made hospitable by a combination of factors, safety of the environment, freedom to engage in any vocation of choice, to seek employment and prosper oneself is at the heart of laying the foundation for an industrialised society. It requires the provision of necessary infrastructure that will be the bedrock or pillars of industrialisation.

As a matter of policy and concrete action, power must be made available to vast sections of the populace. African countries need to explore all available avenues for the provision of electricity to the populace. Good access roads, railways that are functional, and developed sea ports are some of the basic infrastructure that enhances the goal of industrialisation.

(2) Country Fit Industrial Policies: Industrial policy can gain traction when the national commitment of the ruling and bureaucratic elite is clear and genuine. Policies need to reflect the country's capabilities (ADB, 2016). The situation where the industrial programmes of many countries in Africa rely on donor finance, and donor support is unhealthy. Although we have observed over the years financial and material assistance from International Financial Institutions towards building institutional capacity, it has also been noted that this reliance sometimes leads to policy fragmentation and failure (Byiers, Karaki and Vanheukelom, 2017). African governments need to exercise capacity in harmonising donor efforts and contributions, aligning them with the country's strategies, but more importantly look inwards to harness their local resources. The ability or power of African states to do this successfully determines the success or otherwise of industrial policy (Page and Tarp, 2017).

(3) Focus on Labour Intensive Industrialisation: As latecomers in industrialisation, the availability of cheap labour that abounds in Africa should be harnessed. In Africa, capital is scarce, the route to industrialisation is to embark on light industries that will employ as many hands as possible, and getting the able bodied youth involved in productive activities, and away from idleness. This is the preferred option given the weakness of the states in Africa and collapsing markets (see Altenburg and Lutkenhorst, 2015).

(4) Access to Capital and Markets: Industrialisation in Africa can flourish if the avenues for accessing capital are made less strenuous. The government should intervene to make capital acquisition less burdensome and less frustrating. Start-up capital should be provided as incentives to genuine young entrepreneurs, and tax holidays or reliefs to manufacturers. There is an urgent need for a reconfiguration of industrial policy (Hausman, Rodrick and Sabel, 2008) to capture diversity of talents who are enthusiastic to start their own micro and small manufacturing enterprises by providing financial loans and grants, and also intervening to help, if need be, to market these products.

(5) Leadership: Critical to industrialisation success is the emergence of a new knowledgeable and competent leadership (Moghalu, 2018) with the right vision, capacity and courage to 
confront the obstacles that have held Africa down over the years. New leadership is critical to industrialisation in Africa. The old narrative with its depressing reputation has to change. Moghalu argues that the problem facing many African states is the character of leadership, persons who are at the helm of affairs are not only ignorant of the basic demands of good governance, but have an unbearable fixation to old practises that have not advanced the cause of the people (2018). If Africa is serious about industrialisation, the cascading of mediocrity (Onyido, 2018) must seize.

(6) Development of Free Economic Zones and Industrial Parks: African Governments need to create free Economic Zones and Industrial Parks along clusters, with incentives that will activate interest in Manufacturing. For instance, in Nigeria, some clusters have evolved naturally, what is required is the support of the State by creation of an enabling business environment.

\section{Conclusion:}

Industrialisation in Africa has not progressed from its primary stage owing largely to industrial policy flaws. The lack of industrialisation in Africa has been the result of not merely poor policies, but the inconsistency in policy formulation and lack of implementation. The paper contends that the hiatus between rhetorics and action needs to be closed by clearly identifying and prioritising what needs to be done, and how it is to be done. It is necessary to demonstrate by concrete actions that manufacturing is the engine to African development. Rather than the call by most African leaders on their citizens to go back to the farm, the refrain now should be to manufacture local goods in response to the needs of the people. It should be the $21^{\text {st }}$ century clarion call.

\section{References}

Abarche, J. S., Goand, D. S., \& Page, J. (2008). Africa at a Turning Point? Growth, Aid and External Shocks. World Bank: Washington D.C.

Ake, C. (2001). Democracy and Development in Africa. Ibadan: Spectrum Books.

Altenburg, T. (2011). Industrial Policy in Developing Countries: Overview and Lessons from Seven Country Cases. Discussion Paper Bonn Deutsches Institut fur Entwicklungspolitik.

Altenburg, T., \& Lutkenhorst, W. (2018). Industrial Policy in Developing Countries: Failing Markets, Weak States.

Bayart, J., Ellis, S., \& Hibou, B. (1999). From Kleptocracy to the Colonial State in Africa. In Bayart, Ellis \& Hibou (eds). The Criminalisation of the State in Africa. Indiana University Press pp. $1-31$.

Bruce, B., Karaki, K., \& Woolfrey, S. (2018). The Political Economy of Regional Industrialisation Policies. AERC Working Papers.

Carmighani, F, and Mandevile, T. (2010). Never Been Industrialised: A tale of African Structural Change. New York. 
Cardoso, E. (2009). A Brief History of Trade Policies in Brazil: From ISI, Export Promotion and Import Liberalisation to Multi-Lateral and Regional Agreements. Paper delivered at the conference on the Political Economy of Trade Policy in the BRICS. March $27-$ 28, New Orleans, LA.

Cimoli, M., Dosi, G. \& Stigliz, J. (eds) (2009). The Political Economy of Capabilities accumulation. Oxford. Oxford University Press.

Cooke, J., \& Brownie, R. (2014). Africa at Crossroads: Overcoming the Obstacles of Sustained Growth and Economic Transformation. Centre for Strategic and International Studies, New York.

ECA (2013) Industrialising for an Emerging Africa. Issues paper, Abidjan.

Economic Commission for Africa and African Union (2013). Economic Report on Africa: Making the most of Africa's Commodities; Industrialising for Growth, Jobs and Economic Transformation. Addis Ababa.

Eldine-Bessam, H., Gadow, R. \& Arnold, U. (2012). "Industrialisation Strategy based on Import Substitution Trade Policy". In Designing Public Procurement Policy in Developing Countries, Springer New York.

Franko, P. (2007). The Puzzle of Latin American Economic Development. Rowman and Littlefield Publishers.

Grabowski, R. (2015). Deindustrialisation in Africa. In International Journal of African Development Vol. 3, No. 3; pp. $51-67$.

Gumede, V. (2015). Political Economy of Post-Apartheid South Africa. CODESRIA.

Hausman, R., Rodrick, D., \& Sabel, C. F. (2008). Reconfiguring Industrial Policy: A Framework with an Application to South Africa. HKS Working Paper No. Rw P08 031.

Helman, B. \& Ndumbaro, L. (2002). Corruption, Politics and Societal Values in Tanzania: An Evaluation of the Mkapa Administration Anti-Corruption Efforts. African Journal of Political Science 7(1).

International Crisis Group (2006) Nigeria: Want in the midst of plenty.

Malam, J., Steenkamp, E., Roussouw, R., and Viviers, W. (2014). Analysis of export and employment opportunities for South African Manufacturing Industries. Available: http://www.tips.org.29/reseearch-archive-manufacturing-conference-2014/item/2797-analyses-of-export-and-employment-opportunities-from-the-South-Africanmanufacturing-industry

Moghalu, K. (2018). Towards Transformative Leadership in Africa. Paper presented during the Rotary District Conference in Awka at Marble Arch Hotels, May $12^{\text {th }}$. 
Naim, Moses (2000). Washington Consensus or Washington Confusion. Foreign Policy Spring $87-103$.

Onyido, I. (2018). ASUU Ideologies, Principles and Struggles. Address presented during the Commissioning of ASUU Secretariat at Nnamdi Azikiwe University, Awka

Organisation for Economic Cooperation and Development (OECD). (2013). Perspectives on Global Development: Industrial Policies in a Changing World, shifting up a gear (pocket ed.) Paris.

Oyebanke, O. (2015). Industrialisation Pathways to Human Development: Industrial Clusters, Institutions, and Multidimensional Poverty in Nigeria. Paper submitted to the First Annual Bank Conference in Africa: Harnessing Africa's growth for faster Poverty Reduction. Paris School of Economics and World Bank.

Page, J. \& Tarp, F. (eds) (2017). The Practise of Industrial Policy Government Business Coordination in Africa and East Asia. Oxford. Oxford University Press.

Reidel, J. (nd). Development Policy, Industrialisation Strategies, Import Substitution and Export Promotion.

Riedel, J. (2007). The Tyranny of Numbers or The Tyranny of Methodology: Explaining the East Asian Growth Experience, Annals of Economics and Finance 8, 385 - 396.

Rodrick, D. (2002). After Neoliberalism What Next? Remarks at the Brazilian Development Bank (BNDES) Seminar on New Paths of Development, Rio de Janeiro, Sept. 12 - 13

Shakya, M. (2010). The State's Role in Building a Critical Mass for Competitiveness in Apparel Exports. Paper presented at the World Bank African Project.

Stiglitz, J. (1998). More Instruments and Broader Goals: Moving towards the Post Washington Consensus. Helsinki: World Institute for Development Economics Research.

Stiglitz, J. (2016). Can Intra-African Trade Unlock Africa’s Industrialisation?

UNCTAD (2013). Economic Development in Africa Report, Intra African trade: Unlocking Private Sector Dynamism, Geneva. http://unctad.org/en/publications/aldcafrica2013.pdf

UNECA (2011). Industrial Policies for the Structural Transformation of African Economies: Options and Best Practises. Policy Research Report No. 2.

Vanheukelom, J. and T. Bertelsman-Scott (2016). The Political Economy of Regional Integration in Africa: The South African Development Community (SADC) Report. Maastricht: ECDPM.

Whitfield, C., Threkildsen, O., Bur, L., Kjaer, A. M., (2015). The Politics of African Industrial Policy. 
Williamson, J. (2004). The Washington Consensus as Policy Prescription for Development. Lecture delivered at the World Bank, on Jan. 13 in the lecture series, Practitioners of Development.

World Bank (2000). Anti-corruption in Transit: A Contribution to the Policy Debate. World Bank Washington DC. 